\title{
Nonmarital Cohabitation, Marriage, and Health Among Adolescents and Young Adults
}

Michael Pollard and Kathleen Mullan Harris

RAND Labor \& Population

WR-997

May 2013

This paper series made possible by the NIA funded RAND Center for the Study of Aging (P3OAG012815) and the NICHD funded RAND Population Research Center (R24HD050906).

RAND working papers are intended to share researchers' latest findings and to solicit informal peer review. They have been approved for circulation by RAND Labor and Population but have not been formally edited or peer reviewed. Unless otherwise indicated, working papers can be quoted and cited without permission of the author, provided the source is clearly referred to as a working paper. RAND's publications do not necessarily reflect the opinions of its research clients and sponsors. RAND尺 is a registered trademark. 


\title{
NONMARITAL COHABITATION, MARRIAGE, AND HEALTH AMONG ADOLESCENTS AND YOUNG ADULTS
}

\author{
Michael S. Pollard* and Kathleen Mullan Harris** \\ * RAND, Santa Monica, CA \\ ** University of North Carolina - Chapel Hill
}

Corresponding Author: Michael S. Pollard, RAND Corporation, 1776 Main Street, Santa Monica, CA 90407-2138. Phone 310-393-0411 x7627; Fax 310-260-8160;

E-mail: mpollard@rand.org

Work on this project was supported by grant R03 HD060731 from the National Institute on Child Health and Human Development (PI: Michael Pollard).

This research uses data from Add Health, a program project designed by J. Richard Udry, Peter S. Bearman, and Kathleen Mullan Harris, and funded by a grant P01-HD31921 from the National Institute of Child Health and Human Development, with Cooperative funding from 17 other agencies. Special acknowledgment is due Ronald R. Rindfuss and Barbara Entwisle for assistance in the original design. Persons interested in obtaining data files from Add Health should contact Add Health, Carolina Population Center, 123 W. Franklin Street, Chapel Hill, NC 27516-2524 (addhealth@unc.edu) 


\begin{abstract}
A considerable amount of research has established that the married live longer, healthier lives than the previously- and never-married. Similar research on the health benefits of cohabitation is sparse, and virtually nonexistent from adolescence into young adulthood despite substantial levels of cohabitation at these ages. Using longitudinal data from Add Health (1995-2001/2002) and generalized linear model techniques we investigate the impact of nonmarital cohabitation and marriage on a range of physical and mental health indicators and health behaviors. We also consider the mechanisms through which cohabitation affects health (i.e., selection and protection) and contrast the health effects of cohabitation with those reported for marriage at these relatively early ages. Results indicate that the health benefits of marriage among this sample are weaker than expected based on previous studies of marriage and health, but broader than those for cohabitation. This is not unexpected given the relatively young ages of marriage in Add Health compared to other datasets containing respondents at older ages, which comprise much of the previous marriage and health literature. Cohabitors report lower physical health than married or single individuals, but that cohabiting males receive some mental health benefits relative to singles. Cohabiting men and women also engage in some better health behaviors than singles. There also appears to be some selection into cohabitation and marriage by individuals with relatively poor mental health and health behaviors that may contribute to the observed health differentials.
\end{abstract}




\section{NONMARITAL COHABITATION, MARRIAGE, AND HEALTH AMONG ADOLESCENTS AND YOUNG ADULTS}

The rapid rise in nonmarital cohabitation since 1970 has markedly changed the landscape of romantic relationships in the United States; cohabitation has become a normative experience for both men and women by age 25 . The rapid increase in cohabitation raises important concerns about its consequences for the institution of marriage and the lives of individuals involved in this family form, as research indicates that cohabitors hold lower levels of commitment, and cohabitations are more easily dissolved than marriages. Although the prevalence and patterns of cohabitation have generally been well documented, we know very little about the outcomes of nonmarital cohabitation. This is especially true for young participants; despite the increasing significance of cohabitation at younger ages, the cohabitation literature continues to focus on adults, and treats the experiences of cohabitation the same at all ages.

Nonmarital cohabitation has become an integral part of conjugal life in America. There has been an eight-fold increase in the number of cohabiting households since 1970, the growth of which has been accelerating (Seltzer 2004: 922). In 2002, roughly 50\% of women, and $45 \%$ of men had already cohabited outside of marriage by age 25 , with nearly $10 \%$ of males and $16 \%$ of females under age 20 previously in a cohabiting union (Pollard and Harris 2007). In contrast, only $2 \%$ of women had married by age 20 , and $27 \%$ had married by age 25 (Chandra et al. 2005).

Family has a strong influence on health beliefs and behaviors, and is the primary social agent in the promotion of health and well-being. Our earliest and most powerful messages concerning healthy behaviors and risk reduction, such as alcohol consumption and diet, come from the family. Further, one family member's emotional health often has an influence on all members of the family (Booth and Johnson 1994; Hafstrom and Schram 1984).

Recent demographic trends point to an increasing diversity of family structures (Bumpass and Sweet 1989; Raley 2000; Teachman, Tedrow, and Crowder 2000). The rapid increase in cohabitation raises important concerns about its consequences for the lives of individuals involved in this family form; the trends suggest that young people are not turning away from coupling or establishing intimate relationships, as cohabitation increasingly replaces formal marriages (Raley 2000).

Although the prevalence and patterns of cohabitation have been well documented (e.g., Bumpass, Sweet, and Cherlin 1991; Seltzer 2004), we know little about the health outcomes of nonmarital cohabitation - particularly among younger cohabitors - despite substantial levels of cohabitation at these ages. Further, while there is little dispute about the positive impact of marriage on physical and psychological health among older adults (see, e.g., Waite and Gallagher 2000), there is a dearth of research about whether marriage provides similar health benefits to individuals who enter into marriage at relatively young ages.

This study addresses this increasingly important gap in our knowledge of the significance of contemporary unions. We examine in detail several broad health outcomes stemming from cohabitation: physical health, mental well-being, and healthy behaviors. In particular, we address the following questions:

(1) Does cohabitation in adolescence and young adulthood affect health, and if so, in what way? While we explicitly contrast cohabitation effects against marriage, we also anticipate that relative to other studies, marriage among this relatively young sample will have weaker or even negative effects for participants.

(2) If cohabitation affects health, what are the mechanisms through which it does so? 
(3) How do the health effects of cohabitation (if any) compare to the health effects reported for marriage at these relatively early ages?

\section{UNION STATUS AND HEALTH}

Over the past few decades, a considerable amount of research attention has been directed towards understanding the relationships between union status and health (Waite and Gallagher 2000). Consequently, an extensive body of literature now confirms that married people, particularly men, live longer and healthier lives than those who are single, separated or divorced, or widowed. Such conclusions hold for many countries and across many time periods (e.g., Hu and Goldman 1990). Furthermore, research suggests that simply sharing living space with another person does not confer the same health benefits as living with a spouse (Hughes and Gove 1981).

Although differences in mortality rates between the married and unmarried populations were first to be noted, research continues to indicate that, after controlling for age, married people are at lower risk of dying than never-married or formerly married people (Gove 1973; Lillard and Waite 1995; Murray 2000). Important gender differences in the effects of marriage on mortality are also recurrent in the literature. Men appear to reduce their mortality risk more than women through marriage (Hu and Goldman 1990). This "excess mortality" of unmarried individuals has been increasing over time, particularly for divorced men (Hu and Goldman 1990).

\section{Marriage and Health}

The last few decades have seen increasingly detailed investigations of marriage and health. The focus has widened to include an examination of the physical health benefits associated with marriage. Married people (especially men) have fewer health problems, both acute and chronic, than their unmarried counterparts (Gove 1973; Kiecolt-Glaser and Newton 2001; Verbrugge 1979; Waldron, Hughes, and Brooks 1996; Waldron, Weiss, and Hughes 1997; Wyke and Ford 1992). Additionally, self-evaluated health status, which is strongly associated with perceived quality of life (George and Landerman 1984; Okun et al. 1984), is highest among the married population (Idler and Angel 1990; Idler and Kasl 1991; Kaplan, Barell, and Lusky 1988; Mossey and Shapiro 1982).

There is evidence that married people are better off psychologically as well (Gove 1973; Gurin, Veroff, and Feld 1960; Gove, Hughes, and Style 1983; Ross 1995). Studies of mental health, particularly depression, have shown that married people, especially men, enjoy better mental health than those who are not married (Aneshensel, Frerichs, and Clark 1981; French and Williams 2007; Gore and Mangione 1983; Gove and Shin 1989; Radloff 1975; Rosenfeld 1980).

Health behaviors are also related to marital status. For example, research provides evidence of less alcoholism and problem drinking among married men than unmarried men (Horwitz and White 1991; Joung et al. 1995; Layne and Whitehead 1985). Research on obesity also finds that married people have more appropriate body weights than others (Joung et al. 1995), although findings in this area are not as consistent as in the others mentioned (Rauschenbach, Sobal, and Frongillo 1995).

\section{Cohabitation and Health}

Studies of cohabitation and health are scarce. The few studies of which we are aware all suffer from limited health measures, area samples, and/or small sample sizes, and only one (Booth, Rustenbach and McHale 2008) considers adolescent cohabitation (in relation to depression only). 
Research in Europe, where cohabitation has a longer history, suggests that the selfreported health of cohabitors tends to fall between that of married and single persons, with singles reporting the lowest health (Joung et al. 1995; Mastekaasa 1994). A similar pattern emerges for the presence of chronic conditions (Joung et al. 1995). In terms of mental wellbeing, MacDonald, Peacock, and Anderson (1992) reported that cohabitor's average depression scores fell between those of married and single women.

Research on North American cohabitors is less consistent. Research on physical health suggests that the self-reported health of American cohabitors falls between that of married and single persons (Ren 1997), and that a variety of physical health measures for Canadian cohabitors are improved equally to marriage over singlehood (Wu, Penning, Pollard and Hart 2003), or are unaffected by entry into cohabitation (Wu and Hart 2002). Mental health is either not associated with cohabitation (Booth, Rustenbach and McHale 2008; Horwitz and White 1998; Kim and McKenry 2002; Lamb, Lee and DeMaris 2003), is equal within cohabitation and marriage (Ross 1995) or is associated with greater depression than marriage (Brown 2000; Brown, Bulanda and Lee 2005) in the United States; Canadian data suggests no distinction between the mental health benefits of cohabitors or marrieds relative to singles ( $\mathrm{Wu}$, Penning, Pollard and Hart), but also that as the duration of cohabiting and marital unions increases, so does depression (Wu and Hart 2002). Finally, with regard to health risk factors, cohabiting women reported either more alcohol consumption problems than married women (Horwitz and White 1998) or similar levels of alcohol and drug use to married women (Duncan, Wilkerson and England 2006).

The generalizability of all of the previous research suffers from limited (often single) health indicators and controls, and small or area samples. The Canadian studies rely on the 1994-95 National Population Health Survey (NPHS), either cross-sectionally (Wu, Penning, Pollard and Hart) or longitudinally with the 2-year follow-up (Wu and Hart 2002). Although the NPHS contains detailed health information on a nationally representative sample, there is no information on union history, and thus relationship duration and sequencing is unavailable; many unions are likely remarriages or post-divorce cohabitations, both of which complicate the interpretation of results. With the exception of Ren's (1997) study of subjective health (a single measure) and Horwitz and White's (1998) New Jersey area study of depression and alcohol problems among 1,220 young adults, all the studies pertaining to cohabitation and health in the United States are based on the National Survey of Families and Households (NSFH) data from $1987 / 88$ or longitudinally with the addition of the 1992/94 wave. The NSFH contains information on fewer than 700 cohabitors at all ages in Wave 1, and only 131 longitudinally (Brown 2000). Information on first cohabitations and marriages is substantially more scarce, with only 60 cohabitations and 261 marriages to young people ages 18-35 in the first wave (Lamb, Lee and DeMaris 2003).

The use of such limited samples or arrays of health outcomes severely affects the generalizability of these studies, particularly among the young population where cohabitation is the most common exit from singlehood. Further, the health trajectories established in early adulthood have strong implications for health in later life, particularly with regard to health risk behaviours. The present study addresses many of these limitations: the National Longitudinal Study of Adolescent Health provides a wealth of current (2001/02) information regarding romantic unions and health on a very large, nationally representative sample of young adults. 


\section{Theoretical Frameworks}

Although there is a long, clear record of better health among married people compared to the unmarried population, the explanation of how and why this is so is still widely debated and researched (see, e.g., Waite 1995; Wyke and Ford 1992). One issue central to the debate considers the causal ordering of the relationship: does health determine marital status, or does marital status determine health? In the first instance, marriage selection accounts for the observed differences in health, while in the latter, marriage protection contributes to the health differences.

The explanation of why married people enjoy better mental and physical health may be as simple as the notion that healthy people are more likely to marry and remain married. For example, those who are healthier are more likely to be able to participate in social life, including opportunities for courtship. The possibility of selection into marriage has been considered since the mid-1800s, when Farr (1858) first noted the relationship between mortality and marriage in France. He argued that "the children of families which have been afflicted with lunacy are not probably sought in marriage to so great an extent as others....The beautiful, the good, and the healthy are mutually attractive; and their unions are promoted by the parents in France" (p. 509). Since Farr's time, the idea that mentally and physically healthy people are more likely to marry than those who are not has been invoked by a multitude of studies (e.g., Carter and Glick 1976; Goldman 1993, 1994; Retherford 1975).

The second position -- marriage protection -- states that the actual process of living with a spouse confers benefits to both partners; the married state involves environmental, social, and psychological factors that make it a healthier state than an unmarried one. This position can be traced to Emile Durkheim's (1951[1897]) classic study of suicide, in which marriage is thought to exert a positive influence on the individual through role specifications, obligations, and responsibilities to family members. Social isolation has been identified as a major risk factor for morbidity and mortality, with statistical effects comparable to those such as smoking, blood pressure, and obesity (House, Landis and Umberson 1988). Marriage and the family are a primary source of social integration that subsequently provide benefits to the participant at both the individual and societal level; in addition to spousal support, marriage also ties people to other individuals (e.g., spouse's friends), social groups (e.g., in-laws), and institutions (Stolzenberg et al. 1995; Waite 1995) which all expand the individual's social networks and contribute to embeddedness that provides individuals with a sense of order that is important for well-being..

The health benefits of marriage can be traced back to three main sources: social support, social control, and increased material well-being. Extensive research has indicated that social support helps promote mental (e.g., Brown et al. 1986; Cohen and Wills 1985; Aneshensel and Frerichs 1982) and physical health (e.g., Blazer 1982; Broadhead et al. 1983). Quite simply, marriage provides one of the most important sources of social support -- a spouse (Beggs, Haines, and Hurlbert 1996; Johnson 1983), from whom emotional and instrumental support may be readily obtained (Pearlin and Johnson 1977; Ross, Mirowsky, and Goldsteen 1991; Wyke and Ford 1992). In addition to benefits based on proximity, research indicates that spouses have a substantial degree of overlap in their respective social support networks, thus increasing available support sources (Veiel et al. 1991).

The second type of marriage protection stems from social control. Family ties involve elements of meaning and obligation that contribute to social control, which encourages self and external (spousal) regulation of healthy behaviors on the part of both partners (Gove 1972, 1973; Gove, Hughes, and Style 1990; Joung et al. 1995; Ross 1995; Umberson 1992). Marriage can be likened to a long-term investment that may be compromised if partners behave in ways that are inconsistent with that commitment (Becker 1960). Research indicates that this appears to be the 
case, as married people are less likely to engage in negative health behaviors (such as drinking excessively or eating poor diets) than others (Ross, Mirowsky, and Goldsteen 1991; Umberson 1987; Waite 1995), and are most likely to visit the doctor (Verbrugge 1979).

There are clear relationships between socioeconomic status and health (Feinstein 1993; Kuh and Wadsworth 1993; Strauss et al. 1993). Thus, the third protective function of marriage is the increased material well-being derived from the economy of scale and specialization that may occur (Becker 1981), as well as their greater combined wealth and assets (Lupton and Smith 2003). Research also indicates that married men receive higher wages than unmarried men, further increasing marital material well-being (Daniel 1995; Gray and Vanderhart 2000; Korenman and Neumark 1991). Consequently, married people may be able to afford healthier diets and safer surroundings (Pearlin and Johnson 1977; Trovato and Lauris 1989; Waite 1995).

Marriage selection and marriage protection do not necessarily conflict with each other. Most researchers seem to assume that both contribute to health differences between marital statuses. While most studies accept that selectivity may be a factor in the better health of married people, the studies that have empirically tested the assumption (Brown 2000; Hu and Goldman 1990; Kisker and Goldman 1987; Lamb, Lee and Demaris 2003Lillard and Panis 1996; LiviBacci 1984; Mastekaasa 1992; Simon 2002; Wu and Hart 2002; Wu, Penning, Pollard and Hart 2003) suggest that selection into marriage does account at best for some, but not all, of the relationship between marriage and health.

\section{Health Effects of Cohabitation Compared to Marriage}

Despite the wealth of research on marriage and health, apart from the few studies noted above, there has been virtually no research on cohabitation and health, particularly with regard to physical well-being. It is to this gap in our knowledge that the current study is addressed.

It has been argued that the theoretical frameworks surrounding the marriage process can also be applied to the cohabitation process (Landale and Forste 1991). The two processes probably have more commonalties than any other demographic processes. Marriage and cohabitation both involve an intimate (sexual) relationship, sharing the same living quarters, and at least some level of economic consolidation (Davis 1985). Both can occur to people throughout their adult life. Most importantly, both provide a family environment where children are born and raised.

Based on the similarities between marriage and cohabitation, we expect that both union forms will provide similar benefits to their respective participants. However, it is necessary to examine this assumption, as there are also several important differences in the two union forms. While it has been suggested that cohabitation attracts different types of couples than does marriage (Axinn and Thornton 1992; DeMaris and MacDonald 1993; Thompson and Colella 1992; $\mathrm{Wu}, 1999)$, more than half of cohabitations eventually end in marriage (Bumpass and $\mathrm{Lu}$ 2000 ), and more than $60 \%$ of young people ages 20-29 indicate that "living together with someone before marriage is a good way to avoid eventual divorce" (Whitehead and Popenoe 2001: 13). Thus we can not simply draw firm distinctions between union form participants. Further, marriage has undergone a process of deinstitutionalization, with an associated weakening of the social norms defining behaviour within marriage (Cherlin 2004). Participants may be similar, while potential benefits gained from each union form may not.

The role of selection into cohabitation and its effect on subsequent health differences has

been examined by very few studies, but those that do indicate selection accounts for only a small 
degree of difference, if any (Brown 2000; Kim and McKenry 2002; Lamb, Lee and DeMaris 2003; Wu, Penning, Pollard and Hart 2003).

The level of "marriage protection" effects may also differ. Some research indicates that it is not marriage per se that affects social support and subsequent health improvements, but the quality of the relationship (Proulx, Helms, and Buehler 2007; Ren 1997; Umberson et al. 2006). Research has indicated that cohabitors are less happy with their relationships than are married couples (Nock 1995; Pollard and Harris 2003), potentially weakening the social support advantage. Also, while cohabitors may not differ from married couples in their day to day partnership, it is possible that there are substantial differences with respect to long-term union goals (Bumpass et. al 1991; Casper and Sayer 2002). Studies indicate that most cohabitations are temporary and transitory unions (Bumpass and Lu 2000; Bumpass and Sweet 1989). If improved health results from social control, and social control is based on long-term commitment, the impact of social control on cohabitors' health may not be fully realized. Finally, the benefits stemming from increased material well-being may also differ for cohabitors. The wage increase afforded to married men is lower for cohabiting men, while cohabiting women receive no such "wage premium" (Daniel 1995).

\section{Relationships and Health At Younger Ages}

Adolescence (12 to 19 years old) is a time of particular interest to those studying romantic relationships because the capacity for relationships changes drastically during this period (Brooks-Gunn, Petersen and Eichorn 1985; Brown 2006; Collins and Madsen 2006 Erikson 1968; Giordano, Longmore and Manning 2006). To the extent that adolescents of different ages are differentially prepared for relationships, both emotionally and structurally, then the same experiences occurring at different ages should have different associations with later young adult outcomes (Pawlby, Mills and Quinton 1997). It follows that age may be an important moderator of the long-term consequences of cohabitation and marriage experiences during adolescence and young adulthood. Examinations of cohabitation routinely treat cohabitors at all ages the same (Light 2004), or in the cases where age is considered, it is invariably treated strictly as a control (Pawlby, Mills, and Quinon 1997), rather than as a moderator of effects more generally. The sole exceptions appear to be King \& Scott's (2005) and Brown, Bulanda \& Lee's (2005) focus on older cohabitors (50+) as distinct from middle-age cohabitors. Consequently, the moderating role of age on the links between cohabitation and adult outcomes remains an open question involving demographic concerns about age and duration with psychological concerns about age-graded- and experiential development (Wu and Marin 2007).

The life-course perspective (Elder 1998) suggests that the impact that a particular family experience has on an individual depends on the individual's age and life stage. Estimating the overall associations between experiences during at any point from adolescence through late adulthood, and outcomes during any later point, may obscure differences in the implications of similar experiences occurring at different ages. For example, although cohabitation is increasingly normative for young adults, it may have negative consequences for social development if it occurs too early, before other developmental tasks have been completed (Brooks-Gunn, Petersen and Eichorn 1985). Thus, it is reasonable to expect that both cohabitation and marriage may have substantially different implications for the health of participating adolescents and young adults than they do for older adults. For the present study, we consider a younger age range of respondents than much of the prior literature, and while our 
hypotheses on health effects stem from research based on wider/older ranges of respondents, we do not necessarily expect to observe the same effects at these younger ages as are observed at the older ages.

\section{The Present Study}

The first objective of this study is to examine the question: does cohabitation affect health, and if so, in what way(s)? The diversity of measures available through the Add Health study provides a rare opportunity to examine the social determinants of many distinct aspects of health in detail. While we anticipate that the beneficial effects of cohabitation on health will mirror those of marriage, we also recognize that there may be some differences in the magnitude of those advantages resulting from differing union characteristics. While we explicitly contrast cohabitation effects using marriage as a measuring stick, we also anticipate that relative to other studies, marriage among this relatively young sample will have weaker or even negative effects for participants. In some respects, a disproportionate number of marriages by Wave III of Add Health are "early marriages" - the median age at first marriage in the Add Health data here are 20.3 for women and 20.9 for men. In contrast, contemporaneous 2002 data from individuals age 18-40 in the National Survey of Family Growth, Cycle 6, indicates median ages of first marriage of 24.8 for women and 27.3 for men (Goodwin, McGill and Chandra 2007).

Our second objective follows from our first, seeking to resolve the question: how does cohabitation [and early marriage] affect health? Here we are interested in whether the (anticipated) observed differences in health benefits among marital groups may be explained by marriage (cohabitation) selection effects, through controlled social determinants, or whether there are in fact additional health benefits derived from protection effects based on union type. Because respondents are relatively young at Wave 3, physical health differences may be minor, and may not have had time to manifest themselves significantly; we believe that the examination of health behaviors will be particularly relevant because they are more amenable to quicker changes, and are key predictors of future health status as their effects on health compound over time.

Finally, our third objective is to assess cohabitation and early marriage health benefits separately for men and women. It has been repeatedly observed that men gain greater health benefits from marriage than women do (e.g., Cotton 1999; Gove 1972; Gove et al. 1983; Gurin, Veroff, and Feld 1960; Hu and Goldman 1990; Joung et al. 1995), although these findings have more recently been debated with regard to gender differences in mental health (Frech and Williams 2007; Simon 2002; Waite and Gallagher 2000). Both marriage selection and marriage protection effects may contribute to these gender differences in health. For example, it can be argued that the selection process into marriage may be such that physically- or mentally-ill men may have greater difficulty than similarly afflicted women in getting married, based on traditional courtship roles. As well, the social support and control provided according to the marriage protection hypothesis may be the prime source of men's health benefits from marriage, as women are more likely to assume responsibility for the health of household members (Depner and Ingersoll-Dayton 1985). This may also explain why divorced or widowed men appear to have worse health than divorced or widowed women (Gove 1973; Hu and Goldman 1990). Conversely, women's prime source of health benefits from marriage may be from increased material well-being (Lillard and Waite 1995; Ross 1991; Waldron et al. 1996). In light of women's increased labour force participation and economic independence (Oppenheimer 1994), this may contribute to an explanation of why women's health advantage derived from marriage 
has attenuated over time, while men's has not (Hu and Goldman 1990). Based on prior studies on marriage and health, we expect that men may benefit more from cohabitation than women.

\section{DATA AND METHODS \\ Data}

Data for the study come from Waves 1 and 3 of the National Longitudinal Study of Adolescent Health. Add Health is a nationally representative study of adolescents in grades 7 through 12 in the United States in 1995 who have been followed with multiple interview waves into young adulthood. The sampling frame included all high schools in the United States. A stratified, random sample from 80 clusters of schools was selected from this group. Over 90,000 students completed the in-school survey in 1994. Of those, a baseline sample of 20,745 adolescents aged 12-19 was interviewed at home between April and December 1995, between April and August 1996, and again between August 2001 and April 2002. The overall sample is representative of United States schools with respect to region of the country, urbanicity, school type (e.g., public, parochial, private non-religious, military, etc.), ethnicity, and school size.

By Wave III Add Health respondents lived in all 50 states and were engaged in the various domains of late adolescence and young adult life including post-secondary education, the workforce, community and civic involvement, romantic relationships, and parenthood. The Wave III interview was designed to collect data on attitudes, behaviors and outcomes in these domains, with particularly rich and detailed data on romantic relationships, and union and family formation behaviors. Over 15,000 Add Health respondents were re-interviewed at Wave III with longitudinal data over the various waves of interviews. See Harris, Florey, Tabor and Udry (2003) for more details on the Add Health design and longitudinal data.

To examine the influence of union status on individual health, we will investigate (the change in) a variety of health indicators from Wave 1 to Wave 3. Our study sample excludes respondents who were already married or cohabiting at Wave 1 . With this restriction, the final study sample includes 13,159 respondents aged 18-26 at Wave 3 in all union statuses $(6,944$ women and 6,215 men).

\section{Measures}

$\underline{\text { Health Outcomes }}$

Detailed variable descriptions (dependent and independent) are presented in the Appendix. We consider seven health indicators, measuring a person's general physical health, mental health, and health risk behaviors. Physical health is assessed by respondent's self-rated health, an ordinal scale ranging from 1 (poor) to 5 (excellent). The respondent's mental health is assessed using the 10 CES-D items measured by Add Health. ${ }^{1}$ Here we refer to the measure of mental health as more generally assessing "depressed affect" rather than clinical depression.

In addition to physical and mental health, we assess a variety of health risk behaviors. The first set of health behavior includes whether or not the respondent had a physical exam within the past year, the frequency of binge drinking ${ }^{2}$ (defined as 5 or more drinks at once) during the previous year (an ordinal scale from $1=$ never to $7=$ almost/every day), and the number of days in the previous month the respondent smoked and/or chewed tobacco. The second set of health risk behaviors refer generally to body maintenance, and include a measure of

\footnotetext{
${ }^{1}$ Add Health includes a 19-item version of the CES-D in its first two waves, but only 10 are retained in Wave 3 .

${ }^{2}$ Recent research suggests that moderate levels of drinking are predictive of better health, with extreme levels a risk for morbidity and mortality (House et al. 1994).
} 
exercise/physical activity frequency during the previous week (ordinal scale, $0-9$ ) and the (absolute value of the) deviation of body mass index (BMI) outside the "normal healthy" range. ${ }^{3}$

\section{Independent Variables}

The primary independent variable is current union status. Union status is a categorical variable with four categories: cohabiting $(\mathrm{N}=1,081$ women, $848 \mathrm{men})$, married (1,378 women, 857 men), single (out of the parental home) (2,254 women and 2,227 men), and single (living in the parental home), $(\mathrm{N}=2,231$ women, 2,283 men). We use single (out of the parental home) as the reference group in order to compare and contrast groups. Cohabitors are identified by the report that they are currently unmarried but have been "living with someone in a marriage-like relationship" for at least one month. Unlike prior studies, single respondents here are differentiated between living in or outside of the parental home. The Add Health respondents are still relatively young at Wave 3 (18-27), compared to surveys such as the NSFH that have (almost exclusively) been used to examine cohabitation and health in the United States. The presence of parents in the respondent's household should create a very different context than a separate household in terms of all three mechanisms of protection effects: social support, social control, and material well-being. In many respects, living in the parental home may provide the highest levels of each of these among all the groups, and thus it is important to acknowledge parental presence.

To control for the confounding effects of other health determinants, we include several observed individual characteristics that are known to be important. For these reasons, we include three groups of control variables: 1) demographic characteristics, 2) socioeconomic status, and 3) psychological resources. Definitions and information about the coding of these variables are also provided in the Appendix. Unless otherwise noted, control variables are measured at Wave 1 (time 1).

Five demographic variables are included in the analysis. Age is measured in years. Race/ethnicity and immigrant status are treated as dummy variables. The number of the respondent's children present in the household (if any) are also included. For respondents in a current marriage or cohabitation, total relationship duration (in months) is also controlled, with an additional interaction for marital duration. ${ }^{4}$

Two indicators of socioeconomic status (SES) are included: parents' highest educational attainment, and an indicator of respondent's income combined with partner's income (if any) to estimate the available economic resources. ${ }^{5}$

We also include three measures of the psychological resources available to respondents: Coping, self esteem, and religiosity. Active coping or problem solving is measured using a scale based on four items. The self-esteem measure reflects the amount of positive feelings an individual holds about his/herself, with higher scores indicating greater self-esteem. Finally, an ordinal measure of participation in religious services/events is included, as a growing literature also links religiosity with health (Ellison and Levin 1998; Hummer et al. 1999; Koenig et al. 2001; Levin 1994; Musick 1996; Sloan 1999).

Finally, we also control on initial health status from Wave 1 (time 1), effectively estimating residual-change models (also known as auto-regressive models) which are among the

\footnotetext{
${ }^{3} \mathrm{BMI}=$ Weight $(\mathrm{kg}) /$ Height $^{2}$ (meters). BMI $(18.5-24.9)$ is considered normal/healthy (Garrow and Webster 1985).

${ }^{4}$ For marriages preceded by cohabitation with the same partner, duration refers to the entire relationship.

${ }^{5}$ Combined income is measured at Wave 3 (time 2).
} 
most frequently used techniques to examine change over time. Men and women are treated separately in the analysis in order to contrast possible gender differences .

\section{METHODS}

The analysis proceeds in two stages. First we make a series of comparisons to contrast health across union statuses (single living in the parental home, single living outside the parental home, cohabiting, married) to provide an overall qualitative assessment of the differences (Panel $\mathrm{A}$ in the tables). We then add other potentially relevant explanatory factors to study the net impact of cohabitation. Panel B in the tables controls only on respondent age and health condition at Wave 1. Panel $\mathrm{C}$ in the tables adds controls for relationship duration (with an additional interaction for marital duration), and Panel D controls on all factors detailed above.

Because the dependent variables are either dichotomous, ordinal, or continuous, we employ generalized linear models (GLM). For the dichotomous and ordinal response variables (self-rated health, binge drinking, physical in last year, and exercise frequency), the response distribution is assumed to be binomial, and the link functions to be logit. For the continuous response variables (depressed affect, tobacco use, and BMI deviation), the response distribution is assumed to be normal, and the link function to be identity.

The generalized linear model is specified as:

$$
\eta=\Sigma \beta_{\kappa} X_{\kappa}
$$

The identity link function substitutes $(\eta=\mu$ ) into (1), while the logit link function substitutes $\left(\eta=\log _{e}[\mu /(1-\mu)]\right)$.

The parameters were estimated by the maximum likelihood (ML) method using the NewtonRaphson algorithm (McCullagh \& Nelder, 1989).

\section{RESULTS}

\section{Results}

Our analysis begins with a descriptive account of health status differences between union status groups. Our primary concern is the relative health of cohabitors on each of our seven health indicators. Panel A in Table 1A presents a summary of the generalized linear models of the impact of union status on the two general health measures (self-rated health and depressed affect) for women, without controls, in order to indicate qualitative differences between union status groups. The coefficients shown reflect comparisons between each union status group and the single - outside of parental home group, and provide a baseline comparison. The significance of any health differences between the married group and the cohabiting union group is also presented in the Tables. Panel B in Table 1A presents the same information after controlling for respondent age and prior health status (at Wave 1) to assess whether observed differences across union statuses in Panel $\mathrm{A}$ are due to age or initial health differences. Panel $\mathrm{C}$ adds additional controls on details of the unions: duration and presence of children. Cohabiting unions are likely to be of shorter durations than marital unions, and children may be more likely within marriage 
than within cohabitation; both relationship duration and presence of children have implications for health outcomes. Finally, Panel D adds the complete set of controls. ${ }^{6}$

\section{General Health Indicators}

Turning first to women's health, Panel A of Table 1A indicates that there are significant physical and mental health differences among several of the different union status groups. Column 1 includes our measure of self-reported health status. The cohabiting group reports significantly lower health than both the single (out of parental home) and married groups; marrieds are not significantly different from singles. Column 2 includes the measure of depressed affect, and here again, cohabitors report poorer (mental) health than marrieds (but are not significantly different from singles out of the home). As we add controls in Panels B through $\mathrm{D}$ there is little substantive change in cohabiting women's low levels of self-rated health. In the final preferred model, in contrast to expectation, cohabiting women report significantly lower levels of health than all other union statuses.

In Column 2 we do see substantive changes in the union status differences in depressed affect across panels; when age and initial mental health status are controlled, the differences between marrieds and cohabitors become nonsignificant (Panel B). Children are significantly associated with greater depressed affect (Panels $C$ and D), which reverses the sign of the cohabitation effect (to reduced depressed affect); although cohabitors and marrieds are not significantly different from singles out of the parental home in the final model (Panel D), there is the suggestion that women in either type of union have improved mental health relative to singles as anticipated. Singles still living in the parental home do report marginally significantly lower depressed affect relative to singles out of the parental home, although the magnitude of the effect is smaller than that observed for women in unions. ${ }^{7}$

\section{[Table 1A About Here]}

Turning now to the results for men's general health across union status groups in Table 1B, we follow the same procedures as in Table 1A for women. Like their female counterparts, cohabiting men report the lowest levels of self-rated health (Panel A). Single men still living in the parental home also report significantly lower health than singles outside of the parental home, and are not significantly different from the cohabitors. With the addition of relationship duration controls (Panel C), married men additionally report significantly greater health than singles (either in the parental home or not). However, as the marital relationship continues there is apparently a slow decline in health. All of the observed differences continue to hold with the complete array of controls (Panel D).

Men's mental health initially appears to be best among the married and worst for those singles still living with their parents; cohabitors do not report significantly lower levels of depressed affect than do singles out of the parental home, or significantly more than the married (Panel A). With the addition of age and initial level of depressed affect (Panel B), the beneficial effects of union status for both married and cohabiting men are intensified, and both become significantly different from singles (both types); as anticipated, the substantive conclusions are the same after the complete set of controls is added in Panel D.

\footnotetext{
${ }^{6}$ Complete details of the regression results for the control variables are available from the authors. The tables presented below serve primarily to summarize the union status differentials. The control factor effects will be briefly mentioned.

${ }^{7}$ Recall that the number of single cases is substantially greater than cohabitors or marrieds.
} 
[Table 1B About Here]

\section{Health Risk Behaviors}

Table 2A presents the results of the analysis of health behaviors analogous to that in Table 1A. As expected, married women exhibit healthier behaviors than cohabitors (Panel A), although the observed difference between cohabitors and marrieds in receiving an annual physical is not significant (but married women are marginally significantly more likely to receive an annual physical than single women out of the parental household). Cohabitors and singles (both types) are equally likely to receive physicals, but cohabitors are less likely to binge drink than singles out of the parental home; the reduced level of binging for cohabitors is statistically equivalent to that of singles still living with their parents. Married women are the least likely to binge drink. In contrast to expectation, cohabiting women are significantly heavier tobacco consumers than all other groups.

The gradual addition of controls clarifies the union status differences in each of these health behaviors. Panel D shows that married women are more likely to have an annual physical than single (out of the parental home) or cohabiting women (who are not statistically different from singles). However, the older the marital or cohabiting union becomes, the less likely it becomes that women will have a physical. Finally, the presence of children in the household increases the likelihood of an annual physical and reduces binge drinking, but is positively associated with tobacco consumption.

[Table 2A About Here]

The results for the health behaviors of men are presented in Table $2 \mathrm{~B}$, and here as well, the married exhibit healthier behaviors than cohabitors (Panel A); as was the case with the women, the observed difference between cohabitors and marrieds in receiving an annual physical is not significant. In contrast to the findings for the women, however, both married and cohabiting men are significantly less likely to receive an annual physical than single men. As with the women, cohabitors are less likely to binge drink than singles out of the parental home; the reduced level of binging for cohabitors is statistically equivalent to that of singles still living with their parents. Married men are the least likely to binge drink. Again in contrast to expectation, cohabitors are significantly heavier tobacco consumers than all other groups, but different from the women, married men are also significantly higher tobacco consumers than singles.

The addition of age, prior health status, and relationship characteristic controls account for the differences in physicals and tobacco consumption across all union status groups, but the full set of controls actually enhance the differences between union status groups and binge drinking. Children again increase tobacco consumption, but also reduce men's likelihood of receiving an annual physical exam.

[Table 2B About Here]

\section{Body Maintenance}

The final set of tables summarize the GLM regressions of the body maintenance indicators (exercise and BMI deviation) on union status. Panel A of Table 3A indicates that 
married and cohabiting women exercise significantly less than single women (out of the parental home), and that married women also have more abnormal BMIs than any other group, followed by women living at home with their parents. The addition of age and initial body maintenance measures does not attenuate the observed differences in exercise frequency, but does somewhat for BMI deviation. Relationship characteristics also do not attenuate the differences in exercise frequency, although relationship duration does appear to be positively associated with a slight increase in exercise. The substantial increase in BMI deviation associated with marriage appears to be attributable to the presence of children and a gradual increase in BMI abnormality as the marital duration increases (Panel C). With the full array of controls, cohabiting and married women remain significantly less physically active than singles; all union status differences in BMI deviation are attenuated (statistically), although the sign of the union status coefficients and the marginally significant marital duration effect still suggest an elevated abnormality. Presence of children also becomes nonsignificant with regard to BMI.

[Table 3A About Here]

The exercise frequency results for men in Table $3 \mathrm{~B}$ are virtually identical to those observed for women in Table 3A, with the exception that relationship duration is not significantly associated with activity. The results for men's BMI deviation are not consistent with those for women, however. The observed differences in Panel A indicate that single men (outside of the parental home) have significantly more normal BMI scores than the other union statuses (which are equal to one another). With the addition of age and initial BMI deviation controls, married men become significantly more abnormal than cohabitors, who are in turn more abnormal than single men living with their parents (contrast not shown). Married men's BMIs remain significantly more abnormal after the introduction of controls on relationship duration, as well as with the full set of controls. Although the coefficient for cohabitors is positive but not significant in the final model (Panel D), cohabiting relationship duration is significantly associated with a slow increase in BMI abnormality. Single men in the parental home also have significantly greater BMI abnormality than other single men.

\section{Summary of Results}

Overall the results provide more surprises than they do meet standard expectation. Although married women fared best among the groups in terms of many of their healthy behaviors (most likely to receive an annual physical exam, least likely to binge drink, and least frequent tobacco use), the anticipated benefits to mental and physical health were not observed; married women's health was equivalent to that of single women, although at least the direction of the observed relationship between mental health and marriage was in the expected direction, if not at a significant level. Contrary to expectations, married women were among the least physically active. These results are perhaps less surprising once we consider that that these marriages are generally early or young.

As expected, (married) men appeared to gain more health benefits from marriage than women did. Both self-reported and mental health were highest for married men, and binge drinking was lowest. However, tobacco use and physical exams did not vary significantly from singles, but married men exercised least, and had the most abnormal BMIs. 
The health benefits of cohabitation were much less consistent, and were equally or more likely to be health detriments. Returning to our initial research questions, it does appear that cohabitation is linked to health, but not necessarily in the expected manner. For women, cohabitation is generally associated with worse health relative to marriage and singlehood. The exceptions to this are in mental health (where cohabitors report lower depressed affect relative to singles, but not significantly so) and in some health behaviors (binge drinking is lower among cohabitors).

The results for cohabiting men are generally more promising, as we might expect from the research on marriage and health. Cohabiting men reported significantly lower levels of depressed affect than single men, equal to that of married men. Cohabiting men also gained from less frequent binge drinking than singles outside the parental home (but more than married men). Cohabiting men also had more normal BMIs than married men, but which grew less so as the duration of the cohabitation grew longer. However, cohabitation was not related to tobacco use or receipt of annual physicals, and was associated with significantly lower levels of physical activity than singles, and, like among the women, with the lowest self-rated health.

Additionally, throughout the Tables, the observed differences across union status groups were robust to the addition of a range of controls. Despite the addition of controls there was relatively little attenuation in the associations between union status and health outcomes, with the possible exceptions of depressed affect for both men and women, tobacco consumption for men, and BMI for women. There also appeared to be a substantial amount of selection into cohabitation by less healthy (at Wave 1) individuals. The Add Health survey captures respondents at an early stage of the life course, and thus there may also be some form of selection into the (relatively early) marriages we observe by Wave 3 that further contributes to group contrasts.

\section{SUMMARY AND DISCUSSION}

Differences in mental and physical health between married and nonmarried individuals, favouring the married, have been repeatedly observed in the literature. The rapid growth of nonmarital cohabitation, particularly among adolescents and young adults, raises the question as to whether the health benefits thought to be derived from marriage are also experienced by those who participate in this growing family form. The results indicate that cohabiting women tend to receive little positive health benefit, but some significant health detriments, particularly to selfreported health status. Cohabiting men also appear to suffer in terms of self-reported health, but do receive mental health and several other benefits. Marriage at these relatively young ages also appears to have fewer and weaker benefits than the prior literature at older ages would suggest.

Selection effects, both into cohabitation and into marriage, appear to play a role in accounting for some of these health differences. Women in worse mental health and with lower levels of physical activity appear to be selected into unions (either marriage or cohabitation), while both women and men with poor health behaviours, and men with higher levels of depressed affect appear to be particularly selected into cohabitation.

It appears then, that the answer to the question "does cohabitation affect health?" is a qualified "yes", but not always in the beneficial direction. That marriage provides more benefits than cohabitation in terms of physical health may be due in part to the greater autonomy or 
alternatively, a greater lack of commitment, in cohabitation. Perhaps, rather than benefit substantially from the regulation of a partner with long-term obligations, cohabitors may rely primarily on self-regulation of health behaviors. We saw the most consistent benefits of cohabitation arising in health behaviours for both men and women. The significantly reduced levels of problem drinking among the married than the cohabiting hints at this reduced social control within cohabitations as compared to marriages, but to a distinct improvement over singlehood (out of the parental home); cohabitor drinking mimicked singles living with their parents.

The primary health benefit of cohabitation is largely the mental health improvement enjoyed by its male participants. Consistent with MacDonald et al. (1992), cohabitors generally experience less depressive symptoms than those that are not currently in a union. Cohabiting and married men do not differ significantly in terms of depressed affect, consistent with the findings of Horwitz and White (1998). Perhaps the identification of mental health benefits, but not physical health benefits, is in part due to the significantly more developed and refined measures available for mental health. While we have employed more detailed physical health measures than other research, they are still relatively simplistic in comparison to the measures of mental health that have developed out of the more prevalent mental health studies.

As mentioned, there also appear to be some health benefits for cohabitors with respect to risk factors. Cohabiting men and women engage in significantly less problem drinking than singles (out of the home). However, this must be balanced against the lower physical activity of male and female cohabitors (equally poor are the marrieds), and the frequent tobacco consumption of cohabiting women.

While selection effects appear to play some role in the union status health differentials observed, protection effects are the most likely source of benefits. For example, consistent with prior research linking social support to improved health, (e.g., Kessler and Cleary 1980; Thoits 1983), particularly for men, the presence of a cohabiting partner provides increased opportunities for social support, subsequently benefiting mental health. Also consistent with prior research (e.g., Ellison 1991; Kessler and Cleary 1980; Waldron et al. 1996), greater household income is associated with higher self-evaluations of health among both women and men. The added income of a cohabiting partner may similarly provide a protective effect for cohabiting women.

Of note is the less wide-spread effect of marriage on health at these young ages than prior research would lead us to expect. Marriage provides mental and physical health benefits to men. For the women in our sample, however, marriage appears to provide few benefits beyond improved health behaviors. It may be that we have been able to control for a wider range of factors than other studies have previously, subsequently rendering the relationship between marital status and physical health nonsignificant (though we think this to be unlikely). Part of the key to beneficial health effects of marriage may be that the factors contributing to good health stemming from relationships accumulate over time; these marriages may still be too short in duration for benefits to become apparent. It may also be that these relative young, possibly off-time marriages simply do not offer the same types of social support, social control, and increased material well-being that later marriages offer. 


\section{REFERENCES}

Aneshensel, C. S., Frerichs, R. R., and Clark, V. A. 1981. "Family Roles and Sex Differences in Depression." Journal of Health and Social Behavior 22, 379-393.

Artis, J. E. 2007. Maternal Cohabitation and Child Well-Being Among Kindergarten Children. Journal of Marriage and Family 69: 222-236.

Aseltine, R. H. and Kessler, R. C. 1993. "Marital disruption and depression in a community sample." Journal of Health and Social Behavior 34, 237-251.

Axinn, W. G. and Thornton, A. 1992. "The relationship between cohabitation and divorce: Selectivity or causal influence?" Demography 29, 357-374.

Axinn, W. G. and Thornton, A. 1993. "Mothers, children, and cohabitation: The intergenerational effects of attitudes and behavior." American Sociological Review 58, 233-246.

Becker, G. S. 1981. A Treatise on the Family. Cambridge: Harvard University Press.

Beggs, J. J., Haines, V. A., and Hurlbert, J. S. 1996. "Situational contingencies surrounding the receipt of informal support." Social Forces 75, 201-222.

Bennett, N. G., Blanc, A. K., and Bloom, D. E. 1988. "Commitment and the Model Union: Assessing the Link Between Premarital Cohabitation and Subsequent Marital Stability." American Sociological Review 53, 127-138.

Blazer, D. G. 1982. "Social Support and Mortality in an elderly community population." American Journal of Epidemiology 115, 684-694.

Booth, A., Rustenbach, E., and McHale, S. 2008. "Early Family Transitions and Depressive Symptom Changes from Adolescence to Early Adulthood." Journal of Marriage and Family 70: 3-14

Broadhead, W. E., Kaplan, B. H., James, S. A., Wagner, E. H., Schoenbach, V. J., Grimson, R., Heyden, S., Tibblin, G., and Gehlbach, S. H. 1983. "The epidemiologic evidence for a relationship between social support and health." American Journal of Epidemiology 117, 521-537.

Brooks-Gunn, J., Petersen, A. C., \& Eichorn, D. 1985. The study of maturational timing effects in adolescence. Journal of Youth and Adolescence, 14, 149-161.

Brown, S. L. 2000. "The Effect of Union Type on Psychological Well-Being: Depression Among Cohabitors versus Marrieds." Journal of Health and Social Behavior 41: 241255.

Brown, B. B. 2006. A few "course corrections" to Collins \& van Dulmen's "the course of true love". In A. C. Crouter \& A. Booth (Eds.), Romance and sex in adolescence and emerging adulthood: Risks and opportunities (pp. 113-123). Mahwah, NJ: Lawrence Erlbaum Associates Publishers.

Brown, S. L. and Booth, A. 1996. "Cohabitation versus marriage: A comparison of relationship quality." Journal of Marriage and the Family 58, 668-678.

Brown, G. W., Andrews, B., Harris, T., Adler, Z., and Bridge, L. 1986. "Social support, selfesteem and depression." Psychological Medicine 16, 813-831.

Brown, S. L., Bulanda, J. R. and Lee, G. R. 2005. "The significance of nonmarital cohabitation: Marital status and mental health benefits among middle-aged and older adults." Journal of Gerontology: Social Sciences 60B: S21-S29.

Bumpass, L. L. and H-H Lu. 2000. "Trends in Cohabitation and Implications for Children's Family Contexts in the United States." Population Studies 54: 29-41.

Bumpass, L. L. and Sweet, J. A. 1989. "National estimates of cohabitation.” Demography 26, 615-625. 
Bumpass, L. L., Sweet, J. A., and Cherlin, A. 1991. "The role of cohabitation in declining rates of marriage." Journal of Marriage and the Family 53, 913-927.

Carter, H. and Glick, P. C. 1976. Marriage and divorce: A social and economic study.

Cambridge: Harvard University Press.

Chandra, A., Mosher, G., Abma, W.D. \& Jones, J.C. 2005. (2005). Fertility, Family Planning, and Reproductive Health of U.S. Women: Data From the 2002 National Survey of Family Growth. Series 23, no. 25. Hyattsville, MD: National Center for Health Statistics.

Cherlin, A. J. 2004. "The Deinstitutionalization of American Marriage." Journal of Marriage and Family 66: 848-861.

Cohen, S. and Willis, T. A. 1985. "Stress, social support, and the buffering hypothesis." Psychological Bulletin 98, 310-357.

Collins, W. A., and Madsen, S. D. 2006. Personal relationships in adolescence and early adulthood. Pp 191-209 in D. Perlman \& A. Vangelisti (Eds.), Handbook of Personal Relationships. New York: Cambridge University Press.

Cotton, S. R. 1999. "Marital Stress and Mental Health Revisted: Examining the Importance of Risk Factors and Resources." Family Relations 48: 225-233.

Cunningham, M. and Thornton, A. 2006. "The influence of parents' marital quality on adult children's attitudes toward marriage and its alternatives: Main and moderating effects." Demography 43: 659-672.

Daniel, K. 1995. “The Marriage Premium.” Pp. 113-125 in The New Economics of Human Behavior (M. Tommasi and K. Ianlli, eds.). Cambridge: Cambridge University Press.

Davis, K. 1985. "The meaning and significance of marriage in contemporary society." Pp. 1-21 In K. Davis (ed.), Contemporary marriage: Comparative perspectives on a changing institution. New York: Russell Sage.

DeMaris, A. and MacDonald, W. 1993. "Premarital cohabitation and marital instability: A test of the unconventionality hypothesis. Journal of Marriage and the Family 55, 399-407.

Depner, C. and Ingersoll-Dayton, B. 1985. "Conjugal social support: Patterns in later life." Journal of Gerontology, 40, 761-766.

Duncan, G. J., Wilkerson, B. \& England, P. (2006). Cleaning up their act: The effects of marriage and cohabitation on licit and illicit drug use. Demography 43: 691-710.

Durkheim, E. [1897] 1951. Suicide. Glencoe: The Free Press.

Elder, G.H. Jr. 1998. The life course and human development. Pp. 939-991 in Handbook of Child Psychology, Vol 1., Theoretical Models of Human Development (Lerner, R.M. \& Damon, W., eds). New York: Wiley.

Ellison, C. G. 1991. "Religious involvement and subjective well-being." Journal of Health and Social Behavior 32, 80-99.

Ellison, C. G. and J. S. Levin. 1998. "The Religion-Health Connection: Evidence, Theory, and Future Directions." Health Education and Behavior 25: 700-720.

Erikson, E. H. 1968. Identity, youth, and crisis. New York: Norton.

Feinstein, J. S. 1993. "The relationship between socioeconomic status and health: A review of the literature." Milbank Quarterly, 71, 279-322.

Frech, A. and Williams, K. (2007). Depression and the Psychological Benefits of Entering Marriage. Journal of Health and Social Behavior 48: 149-163.

Giordano, P. C., Longmore, M. A., and Manning, W. D. 2006. Gender and the Meanings of Adolescent Romantic Relationships: A Focus on Boys. American Sociological Review 71: 260-287.

Goldman, N. 1993. "Marriage selection and mortality patterns: Inferences and fallacies." Demography 30, 189-198. 
Goldman, N. 1994. "Social factors and health: The causation-selection issue revisited." Proceedings of the National Academy of Sciences, 91,1251-1255.

Goodwin, P., B McGill and A. Chandra. 2009. "Who Marries and When? Age at First Marriage in the United States: 2002" NCHS Data Brief No. 19. Hyattsville, MD: National Center for Health Statistics.

Gore, S. and Mangione, T. W. 1983. "Social roles, sex Roles, and psychological distress." Journal of Health and Social Behavior 24, 300-312.

Gove, W. R. 1972. "The relationship between sex role, marital roles and mental illness." Social Forces 51, 34-44.

Gove, W. R. 1973. "Sex, marital status, and mortality.” American Journal of Sociology, 79, 4567.

Gove, W. R. and Shin H. C. 1989. "The psychological well-Being of divorced and widowed men and women." Journal of Family Issues 10, 122-144.

Gove, W. R., Hughes, M., and Style, C. B. 1983. "Does marriage have positive effects on the psychological well-being of the individual?" Journal of Health and Social Behavior 24, 122-131.

Gray, J. S. and M. J. Vanderhart. 2000. "On The Determination of Wages: Does Marriage Matter?” Pp. 356-367 in The Ties That Bind: Perspectives on Marriage and Cohabitation (L. J. Waite, ed.). New York: Aldine de Gruyter.

Gurin, G., Veroff, J., and Feld, S. 1960. Americans view their mental health. New York: Basic Books.

Halpern-Meekin, S. and Tach, L. 2008. Heterogeneity in Two-Parent Families and Adolescent Well-Being. Journal of Marriage and Family 70: 435-451.

Horwitz, A. V. and White, H. R. 1991. "Becoming married, depression, and alcohol problems among young adults." Journal of Health and Social Behavior 32, 221-237.

Horwitz, A. V. and White, H. R. 1998. "The Relationship of Cohabitation and Mental Health: A Study of a Young Adult Cohort. Journal of Marriage and Family 60: 505-514.

Hu, Y. R. and Goldman, N. 1990. "Mortality differentials by marital status: An international comparison." Demography 27, 233-250.

Hughes, M. and Gove, W. R. 1981. "Living alone, social integration, and mental health." American Journal of Sociology, 87, 48-74.

Idler, E. L. and Angel, R. 1990. "Self-rated health and mortality in the NHANES-I epidemiological follow-up study." American Journal of Public Health 80, 446-452.

Idler, E. L. and Kas1, S. 1991. "Health perceptions and survival: Do global evaluations of health status really predict mortality?" Journal of Gerontology: Social Sciences, 46, S55-S65.

Johnson, C. L. 1983. "Dyadic family relations and social supports." The Gerontologist, 23, 377 383.

Joung, I. M. A., Stronks, K., van de Mheen, H., and J. P. Mackenbach. 1995. "Health behaviors explain part of the differences in self reported health associated with partner/marital status in the Netherlands." Journal of Epidemiology and Community Health 49, 482-488.

Kaplan, G., Barell, V., and Lusky, A. 1988. "Subjective state of health and survival in elderly adults." Journal of Gerontology: Social Sciences, 43, S114-S120.

Kessler, R. C. and Cleary, P. D. 1980. "Social class and psychological distress." American Sociological Review 45, 463-478.

Kim, H. K. and P. C. McKenry. 2002. "The Relationship Between Marriage and Psychological Well-Being." Journal of Family Issues 23: 885-911.

King, V. and M.E. Scott. 2005. "A Comparison of Cohabiting Relationships Among Older and Younger Adults." Journal of Marriage and Family 67: 271-285. 
Koenig, H. G., M. E. McCullough and D. B. Larson. 2001. Handbook of Religion and Health. New York: Oxford University Press.

Korenman, S. and D. Neumark. 1991. "Does Marriage Really Make Men More Productive?" Journal of Human Resources 26: 282-307.

Kuh, D. J. L. and Wadsworth, M. E. J. 1993. "Physical health status at 36 years in a British national birth cohort." Social Science and Medicine 37, 905-916.

Kurdek, L. A. 1991. "The relations between reported well-being and divorce history, availability of a proximate adult, and gender." Journal of Marriage and the Family 53, 71-78.

Lamb, K. A., G. R. Lee, and A. DeMaris. 2003. "Union Formation and Depression: Selection and Relationship Effects." Journal of Marriage and Family 65: 953-962.

Landale, N. and Forste, R. 1991. "Patterns of entry into cohabitation and marriage among mainland Puerto Rican women." Demography 28, 587-607.

Layne, N. and Whitehead, P. C. 1985. "Employment, marital status and alcohol consumption of young Canadian men." Journal of Studies on Alcohol, 46, 538-540.

Levin, J. S. 1994. "Religion and Health: Is There an Association, Is It Valid, and Is It Causal?" Social Science and Medicine 38: 1475-1482.

Light, A. 2004. Gender difference in the marriage and cohabitation income premium. Demography 41: 263-284.

Lillard, L. A. and Panis, C. W. A. 1996. "Marital status and mortality: The role of health." Demography 33, 313-327.

Lillard, L. A. and Waite, L. J. 1995. "Til death do us part: Marital disruption and mortality." American Journal of Sociology, 100, 1131-1156.

Lupton, J. and J. P. Smith. 2003. "Marriage, Assets, and Savings.” Pp. 129-152 in Marriage and the Economy: Theory and Evidence from Industrialized Societies. Cambridge, England: Cambridge University Press.

MacDonald, L. D., Peacock J. L., and Anderson, H. R. 1992. "Marital status: Association with social and economic circumstances, psychological state, and outcomes of pregnancy." Journal of Public Health Medicine 14, 26-34.

Manning, W. D. and Brown, S. 2006. Children's economic well-being in married and cohabiting parent families. Journal of Marriage and Family 68: 345-362.

Mastekaasa, A. 1992. "Marriage and psychological well-being: Some evidence of selection into marriage." Journal of Marriage and the Family 54, 901-911.

Mastekaasa, A. 1994. "The subjective well-being of the previously married: The importance of unmarried cohabitation and time since widowhood or divorce." Social Forces 73, 665692.

McCullagh, P. and Nelder, J. A. 1989. Generalized linear models. Second edition. London: Chapman and Hall.

Mossey, J. M. and Shapiro, E. 1982. "Self-rated health: A predictor of mortality among the elderly." American Journal of Public Health 72, 800-808.

Murray, J. E. 2000. "Marital Protection and Marital Selection: Evidence from a HistoricalProspective Sample of American Men." Demography 37: 511-522

Musick, M. A. 1996. "Religion and Subjective Health Among Black and White Elders." Journal of Health and Social Behavior 37: 221-237.

Newcomb, M. and Butler, P. M. 1980. "Assessment of personality and demographic aspects of cohabitation and marital success." Journal of Personality Assessment, 44, 11-24.

Nock, S. L. 1995. "A comparison of marriages and cohabiting relationships.” Journal of Family Issues 16, 53-76.

Pawlby, S. J., Mills, A., \& Quinton, D. 1997. Vulnerable adolescent girls: Opposite-sex 
relationships. Journal of Child Psychology and Psychiatry, 38, 909-920.

Pearlin, L. I. and Johnson, J. S. 1977. "Marital status, life-strains and depression." American Sociological Review 42, 04-715.

Pollard, M. S. and K. M. Harris. 2003. "Describing Cohabitation and Marriage in Add Health." Paper presented at the Counting Couples II Conference, National Institutes of Health Bethesda, MD, Nov 13-14, 2003.

Pollard, M. S., \& Harris, K. M. 2007. Measuring cohabitation in add health. Pp. 35-52 in S. Hofferth \& L. Casper (Eds.), Handbook of measurement issues in family research. Mahwah, NJ: Erlbaum.

Proulx, C. M., Helms, H. M., and Buehler, C. L. 2007. Marital Quality and Personal WellBeing: A Meta-Analysis. Journal of Marriage and Family 69: 576-593.

Radloff, L. 1975. "Sex differences in depression: The effects of occupation and marital status." Sex Roles 1, 249-265.

Raley, R. K. (2000). Recent Trends and Differentials in Marriage and Cohabitation: The United States. Pp. 19-39 in The Ties That Bind: Perspectives on Marriage and Cohabitation (L. J. Waite, ed). New York: Aldine de Gruyter.

Rauschenbach, B., Sobal, J., and Frongillo, E. A. Jr. 1995. "The influence of change in marital status on weight change over one year." Obesity Research, 3, 319-327.

Raley, R. K. 2000. "Recent Trends and Differentials in Marriage and Cohabitation: The United States." Pp. 19-39 in The Ties That Bind: Perspectives on Marriage and Cohabitation (L. J. Waite, ed). New York: Aldine de Gruyter.

Ren, X. H. S. 1997. "Marital status and quality of relationships: The impact on health perception." Social Science and Medicine 44, 241-249.

Retherford, R. D. 1975. The changing sex differential in mortality. Westport: Greenwood Press.

Roberts, A. 1987. "Psychological characteristics of batterers: A study of 234 men charged with domestic violence offenses." Journal of Family Violence, 2, 81-93.

Rosenfeld, S. 1980. "Sex differences in depression: Do women always have higher rates?" Journal of Health and Social Behavior 21, 33-44.

Ross, C. E. 1991. "Marriage and the sense of control." Journal of Marriage and the Family 53, 831-838.

Ross, C. E. 1995. "Reconceptualizing marital status as a continuum of social attachment." Journal of Marriage and the Family 57, 129-140.

Ross, C. E., Mirowsky, J., and Goldsteen, K. 1990. "The impact of the family on health: The decade in review." Journal of Marriage and the Family 52, 1059-1078.

Seltzer, J. A. 2000. "Families formed outside of marriage." Journal of Marriage and Family 62, $1247-1268$.

Seltzer, J. A. 2004. "Cohabitation in the United States and Britain: Demography Kinship, and the Future." Journal of Marriage and Family 66: 921-928.

Simon, R. W. 2002. "Revisiting the Relationships Among Gender, Marital Status, and Mental Health." American Journal of Sociology 107: 1065-1096.

Simon, R. W. and K. Marcussen. 1999. "Marital Transitions, Marital Beliefs, and Mental Health." Journal of Health and Social Behavior 40: 111-125.

Sloan, R., E. Bagiella and T. Powell. 1999. "Religion, Spirituality, and Medicine." The Lancet 353: 664-667.

Stets, Jan. 1991. "Cohabiting and marital aggression: The role of social isolation." Journal of Marriage and the Family 53, 669 - 680. 
Stolzenberg, R. M., M. Blair-Loy and L. J. Waite. 1995. "Religious Participation Over the Life Course: Age and Family Life Cycle Effects on Church Membership." American Sociological Review 60: 84-103.

Strauss, J., Gertler, P. J. Rahman, O., and Fox, K. 1993. "Gender and life-cycle differentials in the patterns and determinants of adult health." Journal of Human Resources 28, 791-837.

Teachman, J. D., L. M. Tedrow and K. D. Crowder. 2000. "The Changing Demography of America's Families." Journal of Marriage and the Family 62: 1234-1246.

Thoits, P. A. 1983. "Multiple identities and psychological well-being: A reformulation and test of the social isolation hypothesis." American Sociological Review 48, 174-187.

Thompson, E and Collela, U. 1992. "Cohabitation and marital stability: Quality or commitment?" Journal of Marriage and the Family 54, 259-267.

Treas, J. and Giesen, D. 2000. "Sexual infidelity among married and cohabiting Americans." Journal of Marriage and the Family 62, 48-60.

Umberson, D. 1987. "Family status and health behaviors: Social control as a dimension of social integration." Journal of Health and Social Behavior 28, 306-319.

Umberson, D. 1992. "Gender, marital status and the social control of health behavior." Social Science and Medicine 34, 907-917.

Umberson, D., Williams, K., Powers, D. A., Liu, H., and Needham, B. 2006. You Make Me Sick: Marital Quality and Health Over the Life Course. Journal of Health and Social Behavior 47: 1-16.

Verbrugge, L. M. 1979. "Marital status and health." Journal of Marriage and the Family 41, 267-285.

Veiel, H. O. F., Crisand, M., Stroszeck-Somschor, H., and Herrle, J. 1991. "Social support networks of chronically strained couples: Similarity and overlap." Journal of Social and Personal Relationships, 8, 279-292.

Waite, L. J. 1995. “Does marriage matter?” Demography 32: 483-507.

Waite, L.J. and M. Gallagher. 2000. The Case For Marriage. New York: Doubleday.

Waldron, I., Hughes, M.E., and Brooks, T. L. 1996. "Marriage protection and marriage selection - prospective evidence for reciprocal effects of marital status and health." Social Science and Medicine 43, 113-123.

Waldron, I., Weiss, C. C., and Hughes, M. E. 1997. "Marital status effects on health: Are there differences between never married women and divorced and separated women?" Social Science and Medicine 45, 1387-1397.

Whitehead, B. D. and D. Popenoe. 2001. "Who Wants To Marry a Soul Mate?” Pp. 6-16 in The State of Our Unions, 2001. National Marriage Project.

Wickrama, K. A. S., Lorenz, F. O., and Conger, R. D. 1997. "Marital quality and physical illness: A latent growth curve analysis." Journal of Marriage and the Family 59,143-155.

Wu, L. L. \& Martin, S. 2007. Effects of Exposure on Prevalence: Direct and Indirect Effects in a Recursive Hazard Model. Unpublished manuscript.

Wu, Z. and R. Hart. 2002. "The Effects of Marital and Nonmarital Union Transition on Health." Journal of Marriage and Family 64: 420-432.

Wu, Z. M. J. Penning, M. S. Pollard and R. Hart. 2003. ““'In Sickness and In Health”: Does Cohabitation Count?" Journal of Family Issues 24: 811-838.

Wyke, S. and G. Ford. 1992. "Competing explanations for associations between marital status and health." Social Science and Medicine 34, 523-532. 
Table 1A. GLM of General Health Indicators on Union Status, Women, Add Health Wave 3

\begin{tabular}{ccc}
\hline \hline Union Status & $\begin{array}{c}\text { Self-Rated Health } \\
\text { (Ordered Logit) }\end{array}$ & $\begin{array}{c}\text { Depressed Affect (10 item) } \\
\text { (OLS) }\end{array}$ \\
\hline
\end{tabular}

\section{A. Without Controls}

Single (parental home)

Cohabiting

$\begin{array}{lr}-0.033 & -0.121 \\ -0.279^{* * *} & 0.243 \\ -0.01 & -0.103\end{array}$

Married

Single non-parental home (omitted)

F-Ratio Contrast: Cohabiting $=$ Married

$11.99 * * *$

$3.42 \dagger$

-2 Log Likelihood

16694

40370.6

\section{B. Age, Prior Condition Controls}

Single (parental home)

Cohabiting

Married

0.046

$-0.207$

-0.212 **

0.038

0.042

$-0.239$

Single non-parental home (omitted)

F-Ratio Contrast: Cohabiting $=$ Married

10.266 **

2.44

-2 Log Likelihood

15824.3

39538.6

C. Age, Prior Condition,

Relationship Duration Controls

Single (parental home)

Cohabiting

0.045

$-0.204$

-0.196 *

$-0.28$

Married

0.115

$-0.306$

Single non-parental home (omitted)

Duration

$-0.001$

0.015 *

Duration*Married

$-0.002$

$-0.012$

F-Ratio Contrast: Cohabiting $=$ Married

5.02 **

0.01

-2 Log Likelihood

15819.6

39533.1

\section{All Controls ${ }^{\mathrm{a}}$}

Single (parental home)

Cohabiting

Married

$\begin{array}{ll}0.06 & -0.258 \text { * } \\ -0.23 & -0.296 \\ 0.067 & -0.265\end{array}$

Single non-parental home (omitted)

Duration

Duration*Married

$\begin{array}{rr}0 & 0.013 * \\ -0.003 & -0.01 \\ 6.04 * & 0.643\end{array}$

F-Ratio Contrast: Cohabiting $=$ Married

157237

39478.2

-2 Log Likelihood

$\frac{\mathrm{N}}{{ }^{a} \text { Model controls for the explanatory variables shown in Appendix }}$

6882

${ }^{* * *} p<0.001{ }^{* *} p<0.01{ }^{*} p<0.05$ (Two-Tailed Tests); $\dagger p<.05$ (One-Tailed Test) 
Table 1B. GLM of General Health Indicators on Union Status, Men, Add Health Wave 3

\begin{tabular}{lcc}
\hline \hline Union Status & $\begin{array}{c}\text { Self-Rated Health } \\
\text { (Ordered Logistic) }\end{array}$ & $\begin{array}{c}\text { Depressed Affect (10 item) } \\
\text { (OLS) }\end{array}$
\end{tabular}

\section{A. Without Controls}

Single (parental home)

Cohabiting

Married

(Ordered Logistic)

(OLS)

Single non-parental home (omitted)

F-Ratio Contrast: Cohabiting $=$ Married

$\begin{array}{ll}-0.171^{* *} & 0.212 \dagger \\ -0.343^{* * *} & -0.101 \\ -0.09 & -0.315 \text { * }\end{array}$

-2 Log Likelihood

7.508 **

1.29

14353.7

33912.4

\section{B. Age, Prior Condition Controls}

Single (parental home)

Cohabiting

Married

$-0.111 \dagger$

$-0.288^{* * *}$

0.095

$-0.015$

-0.315 *

Single non-parental home (omitted)

F-Ratio Contrast: Cohabiting $=$ Married

8.42 **

0.62

-2 Log Likelihood

13688.2

33256.1

C. Age, Prior Condition,

Relationship Duration Controls

Single (parental home)

Cohabiting

$-0.11+$

-0.253 *

0.096

0.241 *

$-0.192$

Married

$-0.005$

$-0.3$

Single non-parental home (omitted)

Duration

$-0.005$

$-0.007$

Duration*Married

-0.01 *

0

F-Ratio Contrast: Cohabiting $=$ Married

$11.18^{* * *}$

0.15

-2 Log Likelihood

13675.8

33254.2

D. All Controls ${ }^{a}$

Single (parental home)

Cohabiting

Married

-0.122 *

0.011

-0.267 *

-0.326 *

Single non-parental home (omitted)

0.2 *

-0.419 **

Duration

$-0.001$

$-0.008$

Duration*Married

-0.01 *

0.001

F-Ratio Contrast: Cohabiting $=$ Married

$10.57^{\text {** }}$

0.27

-2 Log Likelihood

13616.4

33208.6

$\mathrm{N}$

6182

6140

${ }^{a}$ Model controls for the explanatory variables shown in Appendix

${ }^{* * *} p<0.001{ }^{* *} p<0.01{ }^{*} p<0.05$ (Two-Tailed Tests); $\uparrow p<.05$ (One-Tailed Test) 
Table 2A. GLM of Selected Health Behaviors on Union Status, Women, Add Health Wave 3

\begin{tabular}{|c|c|c|c|}
\hline Union Status & $\begin{array}{l}\text { Physical within year } \\
\text { (Logit) }\end{array}$ & $\begin{array}{l}\text { Binge Drinking } \\
\text { (Ordered Logit) }\end{array}$ & $\begin{array}{l}\text { Tobacco Use (days) } \\
\text { (OLS) }\end{array}$ \\
\hline \multicolumn{4}{|l|}{ A. Without Controls } \\
\hline Single (parental home) & -0.022 & $-0.403^{* * *}$ & -0.534 \\
\hline Cohabiting & -0.001 & $-0.207^{* *}$ & $3.865^{* * *}$ \\
\hline Married & $0.153 \dagger$ & $-1 * * *$ & -0.125 \\
\hline \multicolumn{4}{|l|}{ Single non-parental home (omitted) } \\
\hline F-Ratio Contrast: Cohabiting $=$ Married & 2.355 & $87.17^{* * *}$ & $59.08 * * *$ \\
\hline -2 Log Likelihood & 6980.2 & 16784 & 52259.4 \\
\hline \multicolumn{4}{|l|}{ B. Age, Prior Condition Controls } \\
\hline Single (parental home) & -0.006 & $-0.405 * * *$ & -0.472 \\
\hline Cohabiting & 0.007 & $-0.277^{* * *}$ & $2.065 * * *$ \\
\hline Married & $0.174 *$ & $-1.034 * * *$ & -0.606 \\
\hline \multicolumn{4}{|l|}{ Single non-parental home (omitted) } \\
\hline F-Ratio Contrast: Cohabiting = Married & $2.73 \dagger$ & $77.165^{* * *}$ & $32.14^{\star * \star}$ \\
\hline-2 Log Likelihood & 6956.2 & 16567.7 & 50117.6 \\
\hline \multicolumn{4}{|l|}{$\begin{array}{l}\text { C. Age, Prior Condition, } \\
\text { Relationship Duration Controls }\end{array}$} \\
\hline Single (parental home) & -0.006 & $-0.404^{* * *}$ & -0.467 \\
\hline Cohabiting & 0.135 & -0.089 & $1.964^{* * *}$ \\
\hline Married & $0.366^{* *}$ & $-0.87^{* * *}$ & -0.542 \\
\hline \multicolumn{4}{|l|}{ Single non-parental home (omitted) } \\
\hline Duration & $-0.006 \dagger$ & $-0.009 * *$ & 0.006 \\
\hline Duration*Married & -0.001 & 0.002 & -0.008 \\
\hline F-Ratio Contrast: Cohabiting = Married & 2.227 & $31.86 * * *$ & $10.92^{* * *}$ \\
\hline-2 Log Likelihood & 6949.4 & 16553.7 & 50110.4 \\
\hline \multicolumn{4}{|l|}{ D. All Controls ${ }^{a}$} \\
\hline Single (parental home) & -0.023 & $-0.329 * * *$ & -0.18 \\
\hline Cohabiting & 0.169 & -0.228 * & $1.61^{* *}$ \\
\hline Married & $0.433^{* *}$ & $-1.087^{* * *}$ & $-1.074 *$ \\
\hline \multicolumn{4}{|l|}{ Single non-parental home (omitted) } \\
\hline Duration & -0.005 & $-0.009 * *$ & 0.009 \\
\hline Duration*Married & -0.002 & 0.003 & -0.01 \\
\hline F-Ratio Contrast: Cohabiting $=$ Married & $2.628+$ & $38.793^{* * *}$ & $14.48^{* * *}$ \\
\hline-2 Log Likelihood & 6767.3 & 15875.5 & 49901 \\
\hline $\mathrm{N}$ & 6592 & 6881 & 6710 \\
\hline
\end{tabular}


Table 2B. Selected Health Behaviors on Union Status, Men, Add Health Wave 3

\begin{tabular}{|c|c|c|c|}
\hline Union Status & $\begin{array}{l}\text { Physical within year } \\
\text { (Logit) }\end{array}$ & $\begin{array}{l}\text { Binge Drinking } \\
\text { (Ordered Logit) }\end{array}$ & $\begin{array}{c}\text { Tobacco Use (days) } \\
\text { (OLS) }\end{array}$ \\
\hline \multicolumn{4}{|l|}{ A. Without Controls } \\
\hline Single (parental home) & 0.01 & $-0.415^{* * *}$ & -0.252 \\
\hline Cohabiting & $-0.227^{\star *}$ & $-0.346^{* * *}$ & 2.756 *** \\
\hline Married & $-0.189 *$ & $-0.689 * * *$ & $1.363 *$ \\
\hline \multicolumn{4}{|l|}{ Single non-parental home (omitted) } \\
\hline F-Ratio Contrast: Cohabiting = Married & 0.134 & $14.247^{* * *}$ & $9.803 * * *$ \\
\hline -2 Log Likelihood & 7475.9 & 19643.8 & 48987.8 \\
\hline \multicolumn{4}{|l|}{ B. Age, Prior Condition Controls } \\
\hline Single (parental home) & 0 & $-0.405 * * *$ & -0.406 \\
\hline Cohabiting & $-0.178 *$ & $-0.43^{* * *}$ & $1.011 \dagger$ \\
\hline Married & -0.091 & $-0.721 * * *$ & 0.71 \\
\hline \multicolumn{4}{|l|}{ Single non-parental home (omitted) } \\
\hline F-Ratio Contrast: Cohabiting = Married & 0.694 & $10.089 * *$ & 0.21 \\
\hline-2 Log Likelihood & 7418.6 & 19378.4 & 46871 \\
\hline \multicolumn{4}{|l|}{$\begin{array}{l}\text { C. Age, Prior Condition, } \\
\text { Relationship Duration Controls }\end{array}$} \\
\hline Single (parental home) & -0.001 & $-0.406 * * *$ & -0.411 \\
\hline Cohabiting & -0.1 & $-0.288 * *$ & 0.418 \\
\hline Married & -0.133 & $-0.67^{* * *}$ & -0.844 \\
\hline \multicolumn{4}{|l|}{ Single non-parental home (omitted) } \\
\hline Duration & -0.004 & $-0.008 *$ & 0.034 \\
\hline Duration*Married & 0.006 & 0.005 & 0.038 \\
\hline F-Ratio Contrast: Cohabiting = Married & 0.043 & $7.23^{* *}$ & 1.44 \\
\hline -2 Log Likelihood & 7417 & 19374.9 & 46863.8 \\
\hline \multicolumn{4}{|l|}{ D. All Controls ${ }^{a}$} \\
\hline Single (parental home) & -0.029 & $-0.303^{* * *}$ & 0.212 \\
\hline Cohabiting & -0.076 & $-0.349 * *$ & 0.222 \\
\hline Married & -0.124 & $-0.745^{* * *}$ & -0.951 \\
\hline \multicolumn{4}{|l|}{ Single non-parental home (omitted) } \\
\hline Duration & -0.005 & $-0.006 \dagger$ & 0.034 \\
\hline Duration*Married & 0.007 & 0.005 & 0.038 \\
\hline F-Ratio Contrast: Cohabiting = Married & 0.088 & $7.527 * *$ & 1.28 \\
\hline-2 Log Likelihood & 7253.3 & 18846.5 & 46649.2 \\
\hline $\mathrm{N}$ & 5489 & 6141 & 5943 \\
\hline
\end{tabular}


Table 3A. GLM of Body Maintenance Indicators on Union Status, Women, Add Health Wave 3

\begin{tabular}{lcc}
\hline \hline Union Status & $\begin{array}{c}\text { Exercise Frequency } \\
\text { (Ordered Logit) }\end{array}$ & $\begin{array}{c}\text { BMI Deviation } \\
\text { (OLS) }\end{array}$
\end{tabular}

\section{A. Without Controls}

Single (parental home)

Cohabiting

$-0.064$

$-0.424 * * *$

$0.418^{* * *}$

Married

$-0.364^{* * *}$

0.262

Single non-parental home (omitted)

F-Ratio Contrast: Cohabiting $=$ Married

0.656

0.602 ***

-2 Log Likelihood

28533.3

$1.238^{* * *}$

B. Age, Prior Condition Controls

Single (parental home)

Cohabiting

Married

Single non-parental home (omitted)

F-Ratio Contrast: Cohabiting $=$ Married

1.246

28024.4

-2 Log Likelihood

28159

0.123

$-0.404^{* * *}$

$0.24 \dagger$

$-0.321^{* * *}$

$0.549^{* * *}$

C. Age, Prior Condition, Relationship Duration Controls

Single (parental home)

Cohabiting

Married

Single non-parental home (omitted)

Duration

$-0.026$

$-0.381^{* * *}$

0.12

$-0.345^{* * *}$

0.024

$4.61 *$

Duration*Married

0.002

F-Ratio Contrast: Cohabiting $=$ Married

0.091

25417.4

-2 Log Likelihood

28156.7

25395.8

D. All Controls ${ }^{a}$

Single (parental home)

Cohabiting

Married

Single non-parental home (omitted)

Duration

Duration*Married

$-0.012$

$-0.466^{* * *}$

0.103

$-0.397^{* * *}$

0.13 *

$0.109^{* * *}$

F-Ratio Contrast: Cohabiting $=$ Married

0.002

0.008

$-0.001$

$0.013 \dagger$

0.339

5.76 *

-2 Log Likelihood

28005

25323.8

$\mathrm{N}$

6902

5198

${ }^{a}$ Model controls for the explanatory variables shown in Appendix

${ }^{* * *} p<0.001{ }^{* *} p<0.01{ }^{*} p<0.05$ (Two-Tailed Tests); $\dagger p<.05$ (One-Tailed Test) 
Table 3B. GLM of Body Maintenance Indicators on Union Status, Men, Add Health Wave 3

\begin{tabular}{lcc}
\hline \hline Union Status & $\begin{array}{c}\text { Exercise Frequency } \\
\text { (Ordered Logit) }\end{array}$ & $\begin{array}{c}\text { BMI Deviation } \\
\text { (OLS) }\end{array}$
\end{tabular}

\section{A. Without Controls}

Single (parental home)

Cohabiting

Married

Single non-parental home (omitted)

F-Ratio Contrast: Cohabiting $=$ Married

0.015

$-0.301 * * *$

$-0.478^{* * *}$

4.11 *

27407.5

-2 Log Likelihood

\section{B. Age, Prior Condition Controls}

Single (parental home)

Cohabiting

Married

Single non-parental home (omitted)

F-Ratio Contrast: Cohabiting $=$ Married

-2 Log Likelihood

\section{Age, Prior Condition,}

\section{Relationship Duration Controls}

Single (parental home)

Cohabiting

Married

Single non-parental home (omitted)

Duration

Duration*Married

F-Ratio Contrast: Cohabiting $=$ Married

-2 Log Likelihood

D. All Controls ${ }^{a}$

Single (parental home)

Cohabiting

Married

Single non-parental home (omitted)

Duration

Duration*Married

F-Ratio Contrast: Cohabiting $=$ Married

-2 Log Likelihood
0.025

-0.282 ***

$-0.394^{* * *}$

1.624

27060

0.025

-0.225 *

-0.342 **

$-0.003$

0.001

0.701

27058.8

0.005

-0.196 *

$-0.4^{* * *}$

$-0.004$

0.003

2.32

26993.2

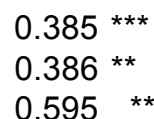

1.48

22794.8

$0.215^{* *}$

$0.402 * * *$

$0.632 * * *$

$3.04 \dagger$

20341.4

$\mathrm{N}$

a Model controls for the explanatory variables shown in Appendix

${ }^{* * *} p<0.001{ }^{* *} p<0.01{ }^{*} p<0.05$ (Two-Tailed Tests); $\dagger p<.05$ (One-Tailed Test) 
Appendix A. Variable Descriptions

\begin{tabular}{|c|c|c|c|c|}
\hline \multirow[b]{2}{*}{ Dependent Variables } & \multicolumn{2}{|c|}{ Females } & \multicolumn{2}{|c|}{ Males } \\
\hline & Mean & S.D. & Mean & S.D. \\
\hline $\begin{array}{l}\text { Self-Rated Health }(1-5) \\
(1=\text { poor, } 5=\text { excellent })\end{array}$ & 3.812 & 0.911 & 3.997 & 0.878 \\
\hline Depressed Affect (0 - 29) & 7.024 & 4.957 & 5.332 & 3.880 \\
\hline Physical Within Year (1=yes) & 0.639 & 0.480 & 0.670 & 0.470 \\
\hline $\begin{array}{l}\text { Binge Drink Within Year }(1-7) \\
(1=\text { never, } 7=\text { almost/every day) }\end{array}$ & 1.503 & 1.116 & 1.751 & 1.406 \\
\hline $\begin{array}{l}\text { Tobacco Use (days / month) } \\
\text { (cigarettes and chewing tobacco) }\end{array}$ & 3.743 & 8.978 & 5.042 & 10.998 \\
\hline $\begin{array}{l}\text { Exercise Frequency Last Week } \\
\text { (range } 0 \text { - 9) }\end{array}$ & 3.295 & 2.003 & 4.144 & 2.164 \\
\hline \multirow{2}{*}{$\begin{array}{l}\text { BMI Deviation } \\
\text { (Deviation from 'normal' range) }\end{array}$} & 0.645 & 1.974 & 0.505 & 1.614 \\
\hline & \multicolumn{2}{|c|}{ Females } & \multicolumn{2}{|c|}{ Males } \\
\hline Independent Variables & Mean & S.D. & Mean & S.D. \\
\hline Age at T2 & 21.788 & 1.730 & 22.022 & 1.744 \\
\hline \multicolumn{5}{|l|}{ Race / Ethnicity (1 = yes) } \\
\hline Black & 0.219 & 0.414 & 0.185 & 0.389 \\
\hline Hispanic & 0.146 & 0.353 & 0.161 & 0.368 \\
\hline $\begin{array}{l}\text { Other } \\
\text { (White = Reference) }\end{array}$ & 0.078 & 0.268 & 0.092 & 0.290 \\
\hline $\begin{array}{l}\text { Immigrant Status }(1=\text { yes }) \\
\text { (First or Second-Generation) }\end{array}$ & 0.198 & 0.398 & 0.217 & 0.412 \\
\hline Combined Income (T2) & 17925.88 & 21657.61 & 18501.16 & 20708.98 \\
\hline $\begin{array}{l}\text { Parents' Highest Education } \\
(1=<\text { high school, } 5=\text { college })\end{array}$ & 2.963 & 1.187 & 3.006 & 1.181 \\
\hline $\begin{array}{l}\text { Religiosity }(0-6) \\
\text { (see Appendix B) }\end{array}$ & 2.987 & 2.181 & 2.733 & 2.177 \\
\hline $\begin{array}{l}\text { Self Esteem }(3-15) \\
\text { (see Appendix B) }\end{array}$ & 6.299 & 2.110 & 5.609 & 1.839 \\
\hline $\begin{array}{l}\text { Coping }(4-20) \\
\text { (see Appendix B) }\end{array}$ & 8.787 & 2.452 & 8.719 & 2.508 \\
\hline Relationship Duration (months) & 9.043 & 16.767 & 5.943 & 13.338 \\
\hline
\end{tabular}

